\title{
COMPARISON OF SHOCK ABSORPTION PERFORMANCE OF BASKETBALL SHOE WITH DIFFERENT SOLE STRUCTURES
}

\author{
Long LIU* \\ Zhengzhou Professional Technical Institute of Electronic \& Information, Henan 450000, China
}

Received: 16.10.2017

Accepted: 15.01 .2018

https://doi.org/10.24264/Ifj.18.1.6

COMPARISON OF SHOCK ABSORPTION PERFORMANCE OF BASKETBALL SHOE WITH DIFFERENT SOLE STRUCTURES

ABSTRACT. Basketball is a sport with high popularity, and it requires high on shoes. In violent experience, feet may be heavily impacted, which may cause damages to joints and nerves. Therefore, feet need the protection and shock absorption of basketball shoes. Today material science develops rapidly; the shock absorption system of basketball shoes is usually borne by the shock absorption property of shoe sole material. In recent years, the special design of basketball shoe sole structure has been a new approach to reduce shock. This study investigated the changes of impulse and pressure of sports shoes with different sole structures during sports through experiments, with the intention of providing a reference for the design and improvement of shock absorption sole of basketball shoes.

KEY WORDS: basketball shoes, sole structure, shock absorption, plantar pressure

COMPARAREA PERFORMANȚEI DE ABSORBTTIE A ȘOCURILOR A ÎNCĂLȚĂMINTEI PENTRU BASCHET CU DIFERITE STRUCTURI ALE TĂLPII REZUMAT. Baschetul este un sport foarte popular, iar cerințele încălțămintei sunt exigente. În urma unei mișcări violente, picioarele pot fi puternic afectate, întâlnindu-se leziuni ale articulațiilor și nervilor. Prin urmare, picioarele au nevoie de protecția și absorbția șocurilor oferite de încălțămintea pentru baschet. Astăzi știința materialelor se dezvoltă rapid. Sistemul de absorbție a șocurilor din încălțămintea pentru baschet constă, de obicei, în proprietatea de absorbție a șocului a materialului din care este confecționată talpa încălțămintei. În ultimii ani, a existat o nouă abordare în designul încălțămintei pentru baschet pentru reducerea șocului. Acest studiu investighează modificările de impuls și presiune ale pantofilor sport cu diferite structuri ale tălpii, cu intenția de a oferi o referință pentru proiectarea pantofilor pentru baschet și îmbunătățirea absorbției șocurilor.

CUVINTE CHEIE: încălțăminte pentru baschet, structură talpă, absorbția șocurilor, presiune plantară

\section{COMPARAISON DE LA PERFORMANCE D’ABSORPTION DES CHOCS DE LA CHAUSSURE DE BASKET-BALL AVEC DES SEMELLES AUX STRUCTURES DIFFÉRENTES}

RÉSUMÉ. Le basket-ball est un sport très populaire, et les exigences de la chaussure sont élevées. Après un mouvement violent, les pieds peuvent être gravement atteints, avec des lésions au niveau des articulations et des nerves. Par conséquent, les pieds ont besoin de la protection et de l'absorption des chocs fournis par les chaussures de basket-ball. Aujourd'hui la science des matériaux se développe rapidement. Le système d'absorption des chocs des chaussures de basket-ball consiste en la propriété d'absorption des chocs du matériau à partir duquel la semelle de la chaussure est fabriquée. Ces dernières années, il y a eu une nouvelle approche de la conception de chaussures de basket-ball pour réduire le choc. Cette étude analyse les changements de pression et d'impulsion des chaussures de sport à semelles différentes, avec l'intention de fournir une référence pour la conception de chaussures de basket-ball et l'amélioration de l'absorption des chocs.

MOTS CLÉS: chaussures de basket-ball, structure de la semelle, absorption des chocs, pression plantaire

\footnotetext{
* Correspondence to: Long LIU, Zhengzhou Professional Technical Institute of Electronic \& Information, Henan 450000, China, email: longl1976@sohu.com
} 


\section{INTRODUCTION}

Basketball shoes usually have a protective effect. Shock absorption is a core part of the protective effect of basketball shoes. The shock absorption sole and structure of basketball shoes is always the key point in relevant studies of shoes manufacturing industry. Xu, W.Q. et al. [1] obtained the maximum deformation of the forefoot and heel of basketball shoes under load, which provided a reference for the shock absorption design of basketball shoes. Isobe, M. et al. [2] quantitatively investigated the effects of outer sole structure on mechanical property through controlling the design of running shoe sole by FEM computer simulation. Iwasa, Y. et al. [3] developed an evaluation method for shock attenuation of shoe sole during landing from a drop jump and found that the main area attenuating the landing force by its compressive deformation in drop jump was the rearfoot of shoe sole; however, the shock attenuation property could be affected by the hardness of the forefoot area if the mechanical conditions of the rear foot area were the same. This study analyzed the impulse and plantar pressure of two materials and verified the shock absorption effect of the soles of the three pairs of basketball shoes by performing plantar pressure test on ANTA core technology based basketball shoes, NIKE air cushion based basketball shoes and shock absorption sole technology based basketball shoes, which provided some suggestions for the manufacture of running shoe soles with shock absorption structure.

\section{Structure of Basketball Shoe Sole}

Basketball shoes are usually composed of upper and sole, and sole is an important part for shock absorption of basketball shoes [4]. Structural shock absorption which emerged in recent years is quite popular. The famous sole structural shock absorption technologies include Nike air cushion technology, ANTA core structure technology and Lining arc structure technology. Following was the introduction of the characteristics of ANTA core technology and Nike cushion technology.

ANTA A-shock core technology is shown in Figure 1. As shown in figure 1, it is the latest core technology of ANTA; a piece of highly elastic core material is placed at the heel of the basketball shoes to simulate trampoline to support feet.

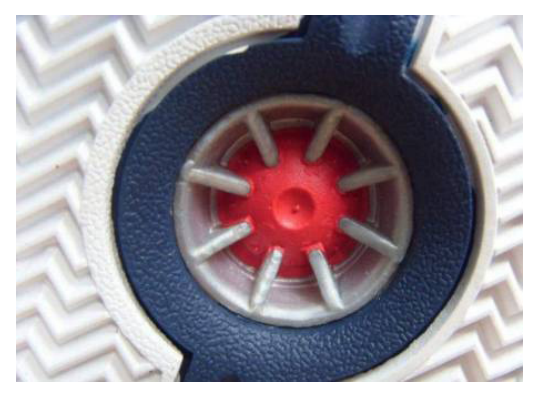

Figure 1. ANTA core technology

Nike air zoom [5] is shown in figure 2. Air zoom is a cushion with an air pressure of 20 PSI and a thickness of $4 \sim 8 \mathrm{~mm}$. The air cushion has excellent rebound performance; hence it has excellent shock absorption and energy regeneration performance.

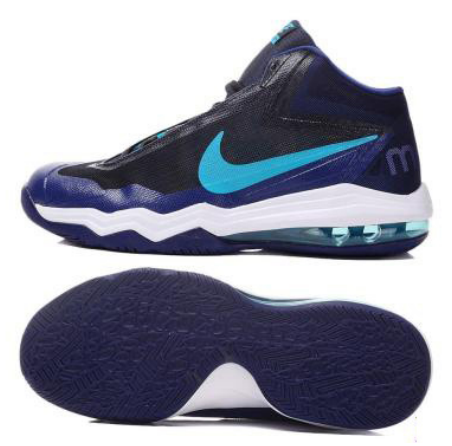

Figure 2. Nike air cushion technology

\section{MATERIALS - PREPARATION OF SOLE WITH SUSPENDED SHOCK ABSORPTION STRUCTURE}

\section{Suspended Shock Absorption Structure}

A suspended shock absorption sole was developed. Three layers of the sole was suspension layer, support layer and skid resistance layer from top to bottom.

The suspension layer was formed by injecting ordinary thermoplastic polyurethane (TPU) [6]. The central part was hollowed out, and then 16 cavities were dug and filled with elastic spheres. In addition, the support layer was mainly made from corn starch/ethylene-vinyl acetate (EVA) composite material. Sixteen spheres with good elasticity which were loosely jointed to be an integral whole penetrated the cavities in the suspension layer and closely adhered to the 
surface of the suspension layer; there was a $2-\mathrm{mm}$ interspace. A shock absorption structure formed based on the rebound and recovery performance of the elastic sphere, which could effectively relieve the momentum and pressure of feet.

Theskid resistance layer was mainly composed of natural rubber. It was connected to the distortionproof layer on the lower surface of the suspension layer. X-shaped anti-skid slot was designed on the layer to increase skid resistance [7].

\section{Manufacturing of Sole Material}

\section{Main Raw Materials and Instruments}

The main raw materials included foodgrade corn starch, talcum powder, EVA, ethyl acetoacetate (solubilizer), polyolefin elastomer (POE), urea (foaming agent) and dicumyl peroxide (DCP).

The main instruments included electronic balance, electronic thermal constant temperature blast drier, internal mixer, open type plastic purificating set, high-speed mixer [8] and plate vulkameter.

\section{Preparation of Corn Starch/EVA Composite}

Firstly EVA was divided into 100 parts by weight. Corn starch was divided into 40 parts. Four-factor and three-level orthogonal experiment was used. POE was represented by $\mathrm{E}$, ethyl acetoacetate by $\mathrm{F}$, and glycerol by $\mathrm{H}$.

Firstly corn starch was dried at $75^{\circ} \mathrm{C}$ for 24 $\mathrm{h}$ using an electrothermal constant-temperature blast drier. After the corn starch was cooled to room temperature, it was mixed with propylene glycol by a high-speed mixer for $10 \mathrm{~min}$. Finally the mixture was sealed and preserved for $45 \mathrm{~h}$.

Smelting test was performed by matching POE, ethyl acetoacetate, talcum powder and glycerol according to Table 1.

Table 1: Different grades for factors

\begin{tabular}{rrrrc}
\hline Grade & E/piece & F/piece & G/piece & H/piece \\
\hline 1 & 10 & 10 & 0 & 5 \\
2 & 20 & 20 & 14 & 10 \\
3 & 30 & 30 & 28 & 15 \\
\hline
\end{tabular}

Composite material was prepared. Firstly EVA, POE, ethyl acetoacetate, talcum powder, glycerol, corn starch and other auxiliaries were weighed according to $L_{9}\left(3^{4}\right)$ orthogonal experiment table [9]. Then they were smelted using an internal mixer for $8 \mathrm{~min}$. The mixed material was taken out when the temperature was between $95^{\circ} \mathrm{C}$ and $100^{\circ} \mathrm{C}$. The mixed material was added into a plastic mixing mill along with DCP and urea for open mill. Foaming was performed when the temperature was between $170^{\circ} \mathrm{C}$ and $180^{\circ} \mathrm{C}$. Finally corn starch/EVA composite was obtained.

\section{The Optimum Performance of the Composite Material}

The physical performance test was performed on the materials. The test indicators included hardness, proportion, tensile property, breaking elongation, tearing property and elasticity. The detection instruments included hardmeter, aerometer, resilience testing machine and electronic universal material testing machine.

Table 2: The detection results of physical properties of corn starch/EVA composite prepared by different formulas

\begin{tabular}{|c|c|c|c|c|c|c|c|}
\hline Experiment & Formula & Hardness/\% & $\begin{array}{l}\text { Density/ } \\
g \times \boldsymbol{m}^{-3}\end{array}$ & $\begin{array}{c}\text { Tensile strength / } \\
\text { MPa }\end{array}$ & $\begin{array}{c}\text { Breaking } \\
\text { elongation /\% }\end{array}$ & $\begin{array}{c}\text { Tearing } \\
\text { strength / } \\
\mathrm{kg} \cdot \mathrm{cm}\end{array}$ & Elasticity /\% \\
\hline 1 & $E_{1} F_{1} G_{1} H_{1}$ & 33 & 0.1023 & 1.18 & 233.16 & 6.94 & 42 \\
\hline 2 & $E_{1} F_{2} G_{2} H_{2}$ & 46 & 0.1089 & 1.25 & 192.57 & 10.92 & 47 \\
\hline 3 & $E_{1} F_{3} G_{3} H_{3}$ & 50 & 0.1323 & 1.43 & 183.49 & 9.76 & 45 \\
\hline 4 & $E_{2} F_{1} G_{2} H_{3}$ & 42 & 0.1125 & 1.72 & 224.31 & 9.11 & 48 \\
\hline 5 & $E_{2} F_{2} G_{3} H_{1}$ & 41 & 0.1097 & 1.51 & 193.46 & 8.49 & 46 \\
\hline 6 & $E_{2} F_{3} G_{1} H_{2}$ & 37 & 0.1064 & 2.36 & 272.13 & 9.42 & 53 \\
\hline
\end{tabular}




\begin{tabular}{llllllll}
7 & $E_{3} F_{1} G_{3} H_{2}$ & 38 & 0.1148 & 1.43 & 176.81 & 8.02 & 48 \\
8 & $E_{3} F_{2} G_{1} H_{3}$ & 44 & 0.1139 & 2.55 & 291.76 & 9.89 & 59 \\
9 & $E_{3} F_{3} G_{2} H_{1}$ & 41 & 0.1002 & 1.94 & 277.36 & 12.21 & 51 \\
\hline
\end{tabular}

The detection results of the performance are shown in Table 2 . The composite prepared in experiment 8 had the best comprehensive mechanical performance and its tensile strength, breaking elongation and elasticity were 2.55 MPa, $291.76 \%$ and $59 \%$ respectively. It indicated that corn starch/EVA composite prepared in experiment 8 had the excellent plasticity and elasticity. Corn starch/EVA composite and suspension shock absorption structure were used in the manufacturing of sole of shoes $A$ in the following test.

\section{TEST SUBJECTS AND METHODS}

\section{Comparison Experiment on the Shock Absorption Performance of Basketball Shoes with Four Different Sole Structures}

\section{Research Subjects}

Ten male university students who were willing to join the test were selected as the research subjects. They were all 23 years old, were $173 \sim 178 \mathrm{~cm}$ high, and weighed $68 \sim 73 \mathrm{~kg}$. Their body mass index (BMI) [10] was between 20 and 25 . The subjects had no clinical history, liked basketball, had no deformity or severe injury in feet, had obvious muscles, kept good physical condition within $24 \mathrm{~h}$ before test, had normal foot joint activities, and received professional basketball skilled action training previously.

Table 3 shows the basic condition of the four pairs of basketball shoes. Shoes A were manufactured by cooperating with a shoe factory and the other three pairs of shoes were purchased from department store. The components of the sole of the four pairs of shoes were similar and the thickness and hardness of the sole were basically the same.

Table 3: The basic conditions of four pairs of basketball shoes

\begin{tabular}{ccccc}
\hline Type & Technology used & $\begin{array}{c}\text { Size } \\
(\text { yard })\end{array}$ & $\begin{array}{c}\text { Weight of a } \\
\text { single shoe }(\mathrm{g})\end{array}$ & Material of external sole \\
\hline Shoes A & $\begin{array}{c}\text { Suspension shock } \\
\text { absorption sole technology }\end{array}$ & 42 & 376.47 & $\begin{array}{c}\text { TPU/corn starch/EVA } \\
\text { composite }\end{array}$ \\
Shoes B & $\begin{array}{c}\text { Nike air Zoom } \\
\text { ANTA A-shock core } \\
\text { technology }\end{array}$ & 42 & 384.62 & XDR rubber \\
Shoes C & 42 & 368.53 & Established EVA/rubber \\
Shoes D (control) & Ordinary structure & 42 & 378.58 & MD \\
\hline
\end{tabular}

\section{Test Method}

(1) Experimental instruments

A foot gauge (Deije shoetools) was used for measuring the size of the ten male university students, and the size of shoes was determined as 42 yard. A plate plantar pressure tester (Beijing Dimeideer Science and Technology Co., Ltd., China) was used for measuring the pressure distribution of feet and ground. An insole plantar pressure tester (Shenzhen Yijie Instrument Co., Ltd., China) was used for measuring the pressure distribution of feet and shoe upper.

(2) Details of test method
The plantar pressure distribution was measured using insole plantar pressure distribution measurement system when the subjects who wore the four pairs of shoes did actions of sudden stop and jump shot. The shock absorption condition of different shock absorption structures was compared in aspects of peak pressure and impulse.

The detailed requirements for the test were as follows.

The experiment was done in a sports biomechanics lab. Tile ground was used in the biomechanics lab to reduce the changes of ground to 
reduce ground deformation. The room temperature of the lab was kept between 20 and $24^{\circ} \mathrm{C}$, and the humidity was kept between $26 \%$ and $40 \%$ [11].

Ten subjects warmed up firstly. Then the subjects who wore different test shoes did actions of sudden stop and jump shot. The forefoot, heel and mid-foot were taken as the main detection and analysis areas. All the subjects joined two tests. In one test, all the subjects were asked to take their shoes off; in the other test, they wore the test shoes. All the subjects should do standard actions of sudden stop and jump shot. The plantar pressure of two feet of the subjects was tested using the plate plantar pressure testing system.

Action of sudden stop [12]: each subject ran on a long runway when wearing no shoes and then stopped suddenly at the center of the pressure testing plate. Relevant parameters at the moment of sudden stop were recorded. After measurement in the barefoot condition, the subjects rested for a while and then started the other test. The pressure was measured for three times, and the average value was taken as the final result.

Action of jump shot: each subject did the action of jump shot when wearing no shoes and wearing four different pairs of basketball shoes. The subjects had a full rest every five minutes. Before test, they practiced the action [13]; after being familiar with the action, each subject took off from both feet and jumped to the same height. One foot landed at the center of the pressure test plate. Every foot was measured for three times. The average value was taken as the final result.

\section{RESULTS AND DISCUSSION}

Through analyzing the average pressure of the left and right foot in standing state, it was found that the pressure of the left foot was smaller than that of the right foot. Therefore the right foot was regarded as the powerful foot. The test data of the right foot were taken as the standard. The plantar pressure and peak plantar pressure were measured using the insole pressure testing system when the subjects wore no shoes and wore the test shoes.

\section{Comparison of Impulse when the Subjects Were Barefoot and when they Wore the Four Pairs of Basketball Shoes}

The computational formula of impulse was: impulse $=F \bullet s$ ( $F$ refers to acting force and $s$ refers to the acting time of force) [14]. Average impulse could reflect the vibration of external force in a certain period. Larger impulse indicated poorer shock absorption performance of basketball shoes.

Finally the impulse during motion were obtained based on the measurement system data and excel, as shown in figures 3 and 4 .

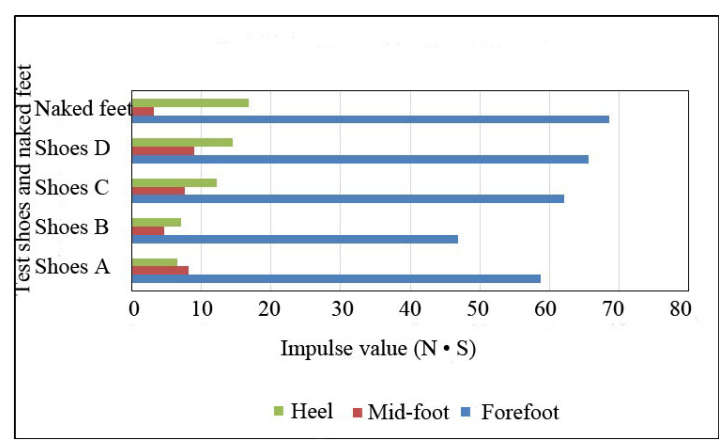

Figure 3. The impulse when the subjects did the action of sudden stop

Figure 3 demonstrated that the impulse of the forefoot was the largest when the subjects were barefoot, followed by shoes D, C, A and B; the impulse of the mid-foot was the largest when the subjects wore shoes $D$, followed by shoes $C$, A, B and barefoot; the impulse of the heel was the largest when the subjects were barefoot, followed by shoes $D, C, B$ and $A$.

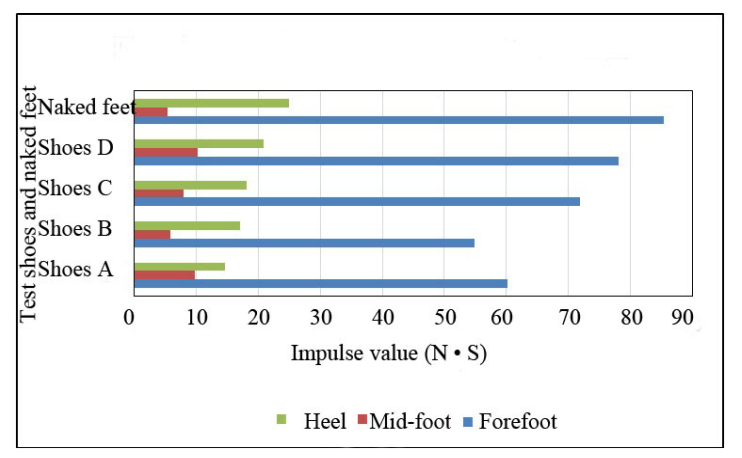

Figure 4. The impulse when the subjects did the action of jump shot

As shown in Figure 4, the impulse of the forefoot was the largest when the subjects did the action of sudden stop barefoot, followed by shoes $D$, $C, A$ and $B$; as to the impulse of the mid-foot, shoes $D$ was the largest, followed by shoes $C, A, B$ and barefoot; as to the impulse of the heel, barefoot was the largest, followed by shoes D, C, B and A. 
In conclusion, the impulse of the forefoot and heel when the subjects wore the four pairs of shoes was smaller than that when the subjects were barefoot, indicating the four pairs of test shoes had certain shock absorption effect; the shock absorption performance of the forefoot part of shoes B was the best, followed by shoes A, C and $D$; the shock absorption performance of the midfoot of the four pairs of shoes was poor, and shoes $B$ was a little better than the others; the shock absorption performance of the heel of shoes $A$ was the best, followed by shoes B, C and D.

\section{Comparison of Plantar Pressure when the Subjects Were Barefoot and when they Wore Four Pairs of Basketball Shoes}

The computational formula of pressure was: pressure $=$ acting force/acting area [15]; peak pressure refers to the largest pressure of an area. During human motion, larger peak pressure indicated larger counter force and severer plantar injury. From a different perspective, peak pressure could also reflect the shock absorption performance of a pair of shoes.

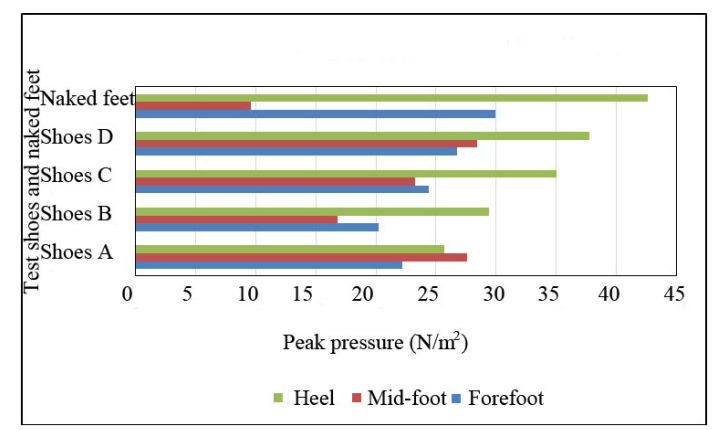

Figure 5. The peak plantar pressure when the subjects did the action of sudden stop

Figure 5 demonstrates that the peak pressure of the forefoot was the largest when the subjects were barefoot, followed by shoes $D, C, A$ and $B$; the peak pressure of the mid-foot was the largest when the subjects wore shoes D, followed by shoes C, A, B and naked feet; the peak pressure of the heel was the largest when the subjects were barefoot, followed by shoes $D$, $C, B$ and $A$.

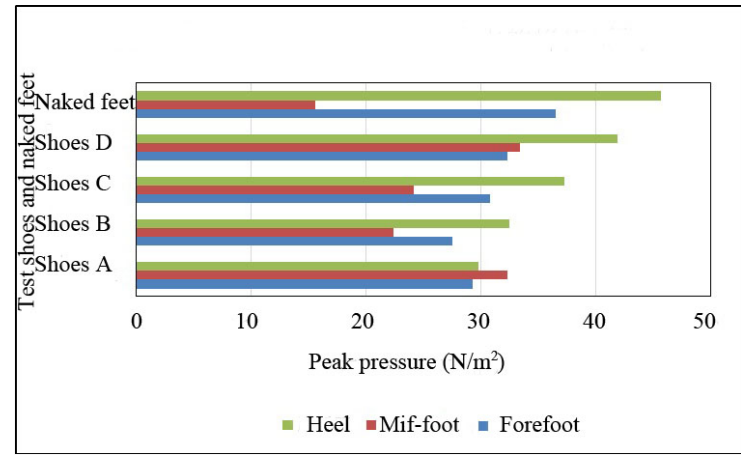

Figure 6. The peak plantar pressure when the subjects did the action of jump shot

Figure 6 suggests that the peak pressure of the forefoot was the largest when the subjects did the action of sudden stop barefoot, followed by shoes $D, C, A$ and $B$; the peak pressure of the mid-foot was the largest when the subjects wore shoes $D$, followed by shoes $C, A, B$ and naked feet; the peak pressure of the heel was the largest when the subjects were barefoot, followed by shoes $D, C, B$ and $A$.

Analysis of the results demonstrated that the peak pressure of the forefoot and heel when the subjects wore one of the four pairs of shoes was smaller than that when the subjects were barefoot, indicating the four pairs of test shoes had certain shock absorption performance; the shock absorption performance of the forefoot of shoes $B$ was excellent, followed by shoes A, C and $D$; the shock absorption performance of the midfoot of the four pairs of shoes was poor, while that of shoes $B$ was better; the shock absorption performance of the heel of shoes $B$ was the best, followed by shoes B, C and D.

\section{CONCLUSIONS}

Two different basketball technical actions and two different test indicators are enough to display the shock absorption performance of basketball shoes. The experimental results demonstrated that all the four pairs of basketball shoes could absorb shock. The shock absorption performance of the forefoot of shoes $B$ was the best, followed by shoes $A, C$ and $D$; air Zoom cushion placed on the forefoot of shoes $B$ had excellent shock absorption performance. The shock absorption performance of the forefoot of shoes A was the second best, suggesting that the suspension shock absorption structure had a favorable shock 
absorption performance on the forefoot. The shock absorption performance of the heel of shoes $A$ was the best, followed by shoes $B, C$ and $D$, indicating that the suspension shock absorption structure had a favorable shock absorption performance on the heel. The shock absorption performance of basketball shoes $A, B$ and $C$ was much better than that of basketball shoes with ordinary sole structure. But the four pairs of basketball shoes could not produce effective shock absorption effect on the mid-foot part.

In conclusion, basketball shoes A with a suspension shock absorption structure had excellent shock absorption performance on the forefoot and heel, superior to ANTA core technology based basketball shoes. Compared to Nike cushion technology which has been matured, the suspension shock absorption structure which was developed in this study was slightly inferior; hence more practice and optimization are needed to improve the shock absorption performance and provide better protection for the feet of basketball players and better wearing experience.

\section{REFERENCES}

1. Xu, W.Q., Hu, W.P., Wang, X.D., Finite Element Analysis on the Reducing Shake and Stopping Sliding Quality of Sport Shoes, Journal of Beijing University of Physical Education, 2012, 11, 71-75.

2. Isobe, M., Moriyasu, K., Nishiwaki, T., Application of numerical simulation to sole structure designing for grip improvement, Symposium on Sports \& Human Dynamics, 2012, 251-254.

3. Iwasa, Y., Isobe, M., Nakaya, S., Tagawa, T., Nishiwaki, T., Evaluation of shock attenuation for indoor shoe sole during landing from a drop jump, Symposium on Sports \& Human Dynamics, 2013, 1-7.

4. Blache, Y., Beguin, A., Monteil, K., Effects of various parameters of basketball shoes on vertical jumping performance: A case study, Science \& Sports, 2011, 26, 1, 48-50, https:// doi.org/10.1016/j.scispo.2010.08.007.

5. Clarke, G.W., Steady progress-Nike Air Zoom Structure 19 evaluation, China Garment, 2015, 22, 90-91.
6. Qu, M.J., Zhang, J.D., Chun, M.A., Ruan, J.Y., Xu, D.C., Liu, Y.X., Study of TPU/Nano-SiO_2/ POM Composite Materials, China Plastics Industry, 2011, 39, 4, 58-57.

7. Yamaguchi, T., Hokkirigawa, K., Development of a high slip-resistant footwear outsole using a hybrid rubber surface pattern, Ind Health, 2014, 52, 5, 414, https://doi.org/10.2486/ indhealth.2014-0105.

8. Guo, L., Wang, C.S., Liu, Q.K., Su, D.J., NewType Vacuumizing Flat Vulcanizing Machine Structure Design and Experimental Research, Key Engineering Materials, 2013, 561, 218-222.

9. Lan, L., Ren, H., Jin, Z., Zhang, L., Cao, X., Orthogonal test of primary recrystallization annealing of grain-oriented silicon steel, Heat Treatment of Metals, 2013, 38, 2, 83-86.

10. Tirosh, A., Shai, I., Afek, A., Dubnovraz, G., Ayalon, N., Adolescent BMI trajectory and risk of diabetes versus coronary disease, $N$ Engl J Med, 2011, 364, 14, 1315, https://doi. org/10.1056/NEJMoa1006992.

11. Lemmahaile, E., Taye, B., Hussen, F., Ergonomic Workstations and WorkRelated Musculoskeletal Disorders in the Clinical Laboratory, Lab Medicine, 2012, 43, Supplement 2, e11-e19, https://doi. org/10.1309/LM7BQ15TTQFBXIS.

12. Proverbio, A.M., Crotti, N., Manfredi, M., Adorni, R., Zani, A., Who needs a referee? How incorrect basketball actions are automatically detected by basketball players' brain, Sci Rep, 2012, 2, 883, https://doi.org/10.1038/ srep00883.

13. Wang, H.K., Un, C.P., Lin, K.H., Chang E.C., Shiang, T.Y., Effect of a combination of wholebody vibration and low resistance jump training on neural adaptation, Res Sports Med, 2014, 22, 2, 161, https://doi.org/10.10 80/15438627.2014.881822.

14. Ameloot, B., Bagust, J. The immediate effect of multiple mechanical impulses on electromyography and pressure pain threshold of lumbar latent trigger points: an experimental study, Chiropr Man Ther, 2016, 24, 1, 20, https://doi.org/10.1186/s12998016-0101-3. 
15. Razak, A.H., Zayegh, A., Begg, R.K., Wahab, Y., Foot plantar pressure measurement system: a review, Sensors, 2012, 12, 7, 9884-9912, https://doi.org/10.3390/s120709884.

16. Wang, M., Lu, A., Zhang, Q., et al., Research Progress on the Impact of Backpacks on Juveniles' Balance, Body posture and Gait (in Chinese), Tiyu Keyan (Sports Scientific Research), 2015, 36, 2, 8-12.

17. Zhou, N., Chen, W., Yang, L., Zhou, J., Application and Perspective of Biomechanics Analytic Technology in Bag Design (in Chinese), Pige Kexue Yu Gongchen (Leather Science and Engineer), 2015, 25, 5, 27-32.

18. Trevelyan, F.C., Legg, S.J., Back pain in school children - Where to from here?, Appl Ergon, 2006, 37, 45-54, https://doi.org/10.1016/j. apergo.2004.02.008.

19. Hong, Y., Brueggemann, G.P., Changes in gait patterns in 10-year-old boys with increasing loads when walking on a treadmill, Gait Posture, 2000, 11, 3, 254-259, https://doi. org/10.1016/S0966-6362(00)00055-2.

20. Zhou, N., Zhou, J., Yang, L., Chen, W., Investigation of the Effect of Varied Schoolbag Weight on the Health of Primary Students: A Quantitative Plantar Pressure Study, Leather and Footwear Journal, 2015, 15, 3, 159-168, https://doi.org/10.24264/Ifj.15.3.3.

21. Negrini, S., Negrini, A., Postural effects of symmetrical and asymmetrical loads on the spines of schoolchildren, Scoliosis, 2007, 2, 8, 1-7, https://doi.org/10.1186/1748-7161-2-8.

22. Marsh, B., DiPonio, L., Yamakawa, K., Khurana, S., Haig, A.J., Changes in Posture and Perceived Exertion in Adolescents Wearing Backpacks with and without Abdominal Supports, Am J Phys Med Rehabil, 2006, 85, 6, 509-515, https://doi.org/10.1097/01. phm.0000219149.14010.d0.

23. Mackie, H.W., Legg, S.J., Beadle, J., Hedderley, D., Comparison of four different backpacks intended for school use, Appl Ergon, 2003, 34, 257-264, https://doi.org/10.1016/S00036870(03)00034-6.

24. Ramadan, M., Al-Shayea, A.M., A modified backpack design for male school children, Int
J Ind Ergonom, 2013, 43, 5, 462-471, https:// doi.org/10.1016/j.ergon.2013.03.002,

25. Yin, Q., Ye, H., Epidemiological Investigation on Pilot's Neck-shoulder-back Pain during Flight (in Chinese), Zhongguo Liaoyang Yixue (China Rehabilitation Medicine), 2002, 11, 4, 48-50.

26. Xu, Z., Yu, B., Wang, F., et al., Investigation and Analysis on Neck-shoulder-back Pain in Mechanized Troops (in Chinese), Beijing Junqu Yiyao (Beijing Military Region Medicine), 1988, 10, 2, 137-138.

27. Macedo, R.B., Coelho-e-Silva, M.J., et al., Quality of life, school backpack weight, and nonspecific low back pain in children and adolescents, J Pediatr (Rio J), 2015, 91, 3, 263-269, https://doi.org/10.1016/j. jped.2014.08.011.

28. Suozzi, B.A., Brazell, H.D., O'Sullivan, D.M., Tulikangas, P.K., A comparison of shoulder pressure among different patient stabilization techniques, Am J Obstet Gynecol, 2013, 209, 478.e1-5, https://doi.org/10.1016/j. ajog.2013.05.037.

29. Martin, J.L., Hooper, R.H., Military load carriage: A novel method of interface pressure analysis. Proceedings of the RTO HTM Specialist's Meeting on Solider Mobility: Innovations in Load Carriage System Design and Evaluation, Kingston, Canada, 2000.

30. Jones, G.R., Hooper, R.H., The effect of singleor multiple-layered garments on interface pressure measured at the backpack-shoulder interface, Appl Ergon, 2005, 36, 79-83, https:// doi.org/10.1016/j.apergo.2004.07.001.

31. Mackie, H.W., Stevenson, J.M., Reid, S.A., Legg, S.J., The effect of simulated school load carriage configurations on shoulder strap tension forcesand shoulderinterface pressure, Appl Ergon, 2005, 36, 199-206, https://doi. org/10.1016/j.apergo.2004.10.007.

(C) 2018 by the author(s). Published by INCDTPICPI, Bucharest, RO. This is an open access article distributed under the terms and conditions of the Creative Commons Attribution license (http:// creativecommons.org/licenses/by/4.0/). 